\title{
BLACK THEOLOGY OF SOUTH AFRICA AND THE LIBERATION PARADIGM
}

\author{
FH Chimhanda \\ Systematic Theology \& Theological Ethics \\ University of South Africa
}

\begin{abstract}
Historically, Black Theology of South Africa, in dialogue with Black Theology of North America, emerged in answer to the problem of apartheid. It was thus situational, regional, liberational and relevant. The apparent dormancy of Black Theology in post-independent South Africa raises questions concerning the liberation agenda in South Africa itself, the rest of Africa and the whole world. The main question is: Has the liberation task been completed? This article explores liberation as an ongoing historical process. Furthermore, the liberation paradigm is seen as multifaceted. In this perspective, liberation is in dialogue with reconciliation, restitution and empowerment of the marginalised. Black Theology then, in dialogue with post-independent Africa, not only has to jealously guard against its hard won liberation from apartheid, but also, needs to be creative and proactive in identifying new needs and in mapping out possible solutions.
\end{abstract}

Key Words: Black Theology of South Africa, Liberation Paradigm, Liberation Agenda, Post-Apartheid and Post-colonial Africa, Dialogical Nature Of Liberation

\section{Introduction}

This article explores Black Theology of South Africa in the context of liberation understood as a historical dynamic process. It seeks to challenge Black Theology to grapple with the liberation of black people (and the people of South Africa as a whole) from old and new forms of oppression that bedevil post-apartheid and multiparty democratic South Africa in particular, and post-colonial black Africa, in general. This is a critical approach seeking to bring into sharp focus structures and issues that make fertile ground for the doing of Black Theology. The spotlight is on interrogating racial, gender, class, ethnical, age and creedal marginalisation. The mutual connectedness of liberation, reconciliation and Black and African Theology is explored. African identity and values are examined in the context of black Africa's contribution to multiparty democracy in a pluralistic, universalising and techno-scientific world.

The pertinent question is: Is the majority of (South) Africans really free, and hence the liberation agenda of Black Theology complete, having gone many years into independence from apartheid and colonialism? As the answer appears negative, we can pursue critical and paradoxical issues that include how Black Theology speaks to inculcating black identity, economic empowerment, black leadership and values, without resorting to reversed racism; the question of black ownership of land while, at the same time addressing the issue of service delivery and sustainable economic environment in a globalising fast changing techno-scientific environment; the transition to African democracy, without exacerbating the apparent cancerous mushrooming of dictatorship governments and of malfunctioning power sharing transitional governments. It is shown that Black Theology's silence on these critical issues accounts for its apparent demise. 
In this creative discourse of Black Theology of South Africa and the liberation paradigm, and as a black woman from across the Limpopo, I position myself as both an insider and outsider with the advantage to give an internal and external critique. This is possible from the perspective of country boarders being fluid, sharing the common identity of both African and Bantu. I am also of the conviction that the distinction between Black Theology and African theology is fluid.

\section{Black Theology's Liberation Agenda}

The Black Theology of South Africa and the Black Theology of North America have one common foundational focus, that is, the liberation from racism (Hopkins 1990:1- 2). In the book, Black Theology in the USA and South Africa, Hopkins (1989:x-xii) affirms this connectivity of purpose. Where Black Theology in the USA addressed racial oppression of blacks that has its roots in slavery, the Black Theology in South Africa focused on liberation from apartheid rule. Black Theology's agenda is to explore black consciousness and power to liberate the black poor fully culturally, politically and spiritually (Hopkins 1989:xvii).

The tenets of Black Theology include: black experience as a point of departure; liberation process modelled on God/Christ (liberator) who takes the side of the oppressed; and active engagement in the liberation process. With liberation from apartheid and colonial oppression, Black Theology is taking another turn to work for authentic liberation and this process is inclusive of reconciliation and nation-building on the road to true African democracy. To bring the liberation agenda of Black Theology into sharp relief, we will examine these constitutive factors in the backdrop of post-apartheid South Africa in relation to postcolonial Africa.

\section{Liberation and Reconciliation}

James Deotis Roberts, in his books Liberation and reconciliation (1994) and Black Theology in dialogue (1987), explains the mutual link of liberation and reconciliation as anchored in God/Christ's salvific will and mission. Roberts (1987:18) exposed the paradox of the human condition: that sin tarnishes both the oppressed and the oppressor and that in a twist of irony, "sometimes the oppressed are also oppressors". Sometimes it is observed that the oppressed of erstwhile are oppressors of today. He concludes that Black Theologians must recognise that "God cares for the oppressed but God also has salvific concern for the oppressors". Liberation, understood in this way is a very complex process that involves the whole nation.

Unpacking the mutual relation of liberation and reconciliation, Schreiter (1992:6) warns against limiting liberation to the revolutionary struggle with the result that there is superficial separation of the two concepts. He is emphatic that reconciliation is not an alternative to liberation and that there is no reconciliation without liberation. Schreiter explains that those who see liberation as ending with the revolutionary struggle fail to recognise the dimensions of conflict, especially when the causes of conflict are hidden, and the violence perpetrated is covert in nature. Alexander Solzhenitsyn (cf. Sparks 2003:147) highlights the link between liberation and reconciliation that is necessary for true democracy saying:

By not dealing with past human rights violations, we are not simply protecting the perpetrators' trivial old age; we are thereby ripping the foundations of justice from beneath new generations.

A proper understanding of the process of reconciliation in post-colonial and post-apartheid Africa is necessary if reconciliation is to be holistic and inclusive of all people and not 
spurious. Schreiter (1992:5-9) explains that reconciliation is central to God's salvific work, and that from the outset God in Christ initiates the process and sees it to its ultimate conclusion. He warns that authentic reconciliation must not trivialise the suffering of the people and that the process is different from arbitration.

It can be said then, that the Black Theology of liberation has taken a new turn in the postapartheid and post-colonial Africa's landscape. In the transition to democracy from apartheid South Africa, Black theologians recognised the mutual connection between liberation and achieving authentic peace and reconciliation. South Africa is commended worldwide for its Kairos Document ${ }^{1}$ (1985) reflections that led to the setting up of the Truth and Reconciliation Commission (TRC) headed by the Nobel Peace Prize laureate (1984), Archbishop Desmond Tutu. The South African TRC, with all its strengths and weaknesses has become exemplary for post-colonial strife-torn countries in transition to democracy (Zimbabwe, Kenya, Liberia etc.). In these countries, it appears that spurious reconciliation is the underlying factor to the existence of dictatorship governments refusing to concede an election defeat. The latter factor, in turn, lead to the mushrooming of power sharing governments.

Tutu explains that real healing results from having dealt with the real situation (1999:218). He makes important recommendations undergirding the reconciliation process: that reconciliation must not be cheap (spurious); for the victims of war atrocities, the main thrust is "anamnesis" (recollection) of the painful memories; that perpetrators of oppression must be held to account for their deeds and ask for forgiveness in return for pardon; and that the process of narrating the harrowing experiences of oppression from apartheid to a supportive and non-judgmental audience is cathartic (Tutu 1999:279).

Recognising that reconciliation, like liberation theology is an on-going dynamic process and also the limitations of the TRC (eg not all cases of atrocities were covered, and, having opened wounds, one must see the patient through the whole healing process) the challenge for Black Theology in post-apartheid South Africa today is to go behind and beyond the TRC.

\section{Black Theology as Dialogical in Nature and Method}

The point of departure for Black Theology of liberation is critical reflection on black experience of marginalisation and oppression in the light of biblical faith. The method includes identifying pockets of marginalisation and oppression, critical analysis taking the OT and NT liberation paradigm of the Christian God (the black God, black Christ - Liberator) who identifies with the oppressed and engages actively in the liberation process (Roberts 1994:ix; Boesak 1976:20-22; Cone 1975:81-82 ff; Mosala 1989:14-15). In multiracial and multicultural democratic South Africa and the apparent need for a holistic vision for the liberation of all people in the real world we recognise a situation that requires "new wine, new wine skins" (Roberts 1994:10,14). The big challenge for Black Theology's critical instrument is to provide a new hermeneutic of blackness, poverty or marginalisation, democracy and leadership. Black Theology opts for prophetic advocacy in providing a critical instrument for keeping the liberation process in checks and balance. In this context, liberation theology has to labour for intellectual rigour and ethical integrity (Roberts 1987:18).

\footnotetext{
A theological statement issued in 1985 by a group of black South African theologians challenging the churches to respond to vicious policies of the Apartheid state under the State of Emergency declared on 21 July 1985 (Wikipedia free encyclopaedia).
} 


\section{The Current Situation of Black Oppression in Post-apartheid and Post-colonial Africa}

In post-apartheid South Africa, sixteen years into multiparty democracy, we can pose to ask whether blacks are really free. The answer is negative, because apparently there is still what Hopkins (1987:xiv) called the "multilayered reality of black oppression" through subtle and overt racism. There are many black people living below the poverty line. The level of illiteracy among blacks is still very high. There are thousands of poor landless blacks clamouring to be resettled (Du Toit 2009:22). In a patriarchal society and the high prevalence of HIV/ AIDS (where poverty and disease are mutually influencing), black women in particular bear the brunt of racial, gender, and class marginalizations.

Simon Maimela (in his speech at the launching of his Festschrift ${ }^{2}$ (Pretoria, 13 August 2010) mentioned gender equality in relation to engaging black women in academic discourse as one of the challenges of Black Theology today. Before him, Maluleke (1997:42) advocated that Black and African theologians must agonise about the challenges posed on them by black feminist theologians.

While it is true that black women are top on the scale of affirmative action, in reality employers do not always meet this requirement. Black women often struggle for the right to equal pay and working conditions with their white counterparts at work place (I have witnessed black women go on strike at a pre-school in Pretoria North, February-March 2010).

The picture about the marginalisation of black people is exacerbated by the fact that there is an emergent black elite making up black leadership and that is sometimes accused of corruption, nepotism, poor service delivery and lack of expertise. Consequently, among poor blacks themselves, there are often mass protests against poor service delivery. In this context, it is as Du Toit (2009:16) says that no affluent black can dissociate him/herself from the lot of blacks living in poverty.

The situation is paradoxical in that while the new South Africa is rated high on the global level as very developed to the extent of competing with the so-called First World, it also has a very high crime rate on the global level (Du Toit 2009:23-24). And, concerning South Africa's relation with post-colonial Africa, particularly with its status of being the last colony to be liberated, Du Toit (2009:16) rightly points out that South African blacks cannot dissociate themselves from the lot of Africans beyond the Limpopo. On the contrary, there are often disturbing occurrences of xenophobic attacks. These are apparently instigated by frustration from lack of employment. This clearly shows a lack of tolerance of refugees - blacks from troubled parts of Africa, including neighbours from across the Limpopo.

It can be said that xenophobic attacks are only the tip of the iceberg for an explosive situation. They are negative signs for a vicious chain of events surrounding economic and political refugees from post-colonial Africa. A good number of them are non-persons with no proper identity documents. These people are open to exploitation through cheap labour. And, because necessity knows no law, in destitution, some of the refugees resort to prostitution and crime and this contributes to the rise in the crime rate of a country. However, some local criminals project their acts on refugees. The Human Rights Watch Organisation, in its document, Neighbours in need, Zimbabweans seek refuge in South Africa (2008) highlights this phenomenon surrounding the plight of refugees in a host country.

Simon Maimela’s Festschrift published in the journal, Studia Historiae, Ecclesiasticae, July 2010. 
There is also the phenomenon of the brain drain connected with the influx of economic refugees into a country that further impoverishes the country of origin. It is common knowledge that governments invest a lot of money and other resources into education. The budget allocation for the Ministry of Education is usually the second highest - after the allocations of the Ministries of Defence and Health.

Westernisation and the fast changing global techno-scientific economy have eroded the African extended family and cultural values based on ubuntu (togetherness, communal identity and solidarity). In this "global apartheid", Du Toit (2009:18) asks an incisive question, "How can a rural black person combat globalization, regionalism, lack of investment and the international community's relative aloofness from Africa?"

While the new South Africa has embarked on land acquisition, restitution and distribution to landless blacks, the situation on the ground is that thousands of poor blacks are still waiting for the ANC government to fulfil its promise on coming to power in 1994 (of meeting the target of redistributing 30 percent of agrarian land to black majority by 2014). Statistics show that on a "willing-buyer, willing-seller" policy, to date, the government has managed to acquire only four percent from private owners (ZimOnline, Wednesday 3 March 2010).

Affirmative action, in favour of the marginalised blacks in the apartheid era has seen the introduction of government policies, in particular, the Black Economic Empowerment (BEE). These policies can be seen to be counter-effective, especially when considering the whole picture of national development and peaceful multicultural living. The policies have to be well planned to empower both the target group and all people. Today, for example, $\mathrm{BEE}$ is criticised as having a negative effect on economic growth and service delivery. Furthermore, the white minority now complain of being marginalised.

Post-colonial African democracy is characterised by dictatorship one-party states, power-sharing governments (as a result of political leaders refusing to concede having lost an election), a history of coups and civil strife, crimes against humanity as a result of governments carrying out punitive measures on opposing nationals and the high number of political and economic refugees (Zimbabwe, Kenya).

There is need for a hermeneutic of suspicion on dubious interventions in the drive for affirmative action for blacks. Otherwise, if Black Theology advocates the liberation of blacks only, the negative critique is that it is monolithic, spurious and sinful in that it advocates reversed racism. Clearly, the struggle for liberation is not over. The task for Black Theology of the "signs of the times" is to establish new needs and new solutions in the transition to authentic democracy in Africa.

\section{Black Theology in Creative Dialogue with Politics: New Wine and New Wine Skins}

In the transition to authentic democracy in Africa, Black Theology's critical tool needs to be sharp enough to disseminate primary factors in the marginalisation of (black) people in a multicultural, interethnic, democratic, and techno-scientific globalising economy. The spotlight is on exploring authentic black empowerment for inclusive multicultural living.

In post-apartheid South Africa, particularly as reflected by the constitution, BEE policy was committed to take on board the economically marginalised and impoverished blacks so that they can have a share in the country's heritage. Affirmative action under this scheme was in favour of emerging black businessmen and women (including white women in addressing gender imbalances that made black women doubly marginalised and white 
women more marginalised than their male counterparts). But although most South Africans agree with this policy in principle, they are disgruntled by the way it is implemented. According to Peng (2008:29), BEE is negated as "intrusive, setting quotas and timetables in terms of black ownership, executive positions, employment and affirmative action procurement". Furthermore, "although BEE has created new black elite, it has not created jobs for the millions of poor and unemployed blacks".

The quest for black economic and political empowerment necessitates the interrogation of both the practice of racism and African democracy operative in post-apartheid South Africa as well as post-colonial Africa. Mokgethi Motlhabi (in his article, "Black Theology and authority”, 1989, cf. Kee in Roberts 2005:50-52), recognising the mutual link between politics and racism, postulates that racism is a myth. In this he identifies racism as a secondary factor in the marginalisation and impoverishment of black masses in the new South Africa and shows that power games are the root cause of black oppression. From this stance, Motlhabi concludes that no radical change will take place without attacking the causes of the myth since the removal of racism would not in itself change the status quo (cf. Knee in Roberts 2005:50). This observation is insightful to the critical analysis of the black situation of oppression.

It is clear that in the new South Africa there is a black/white people divide - an overt and subtle racism, but as Du Toit (2009:28) points out, neither side openly owns to it in the new situation where apartheid is openly denounced as illegal. However, it can be said that subtle racism is legalised in policies like BEE, a situation that Black Theology as critical instrument needs to interrogate.

An important example in this context is that black political leaders in the new South Africa (and post-colonial Africa) have been co-opted into the old colonial, capitalistic model of operation. The result of this is that the emergent black elite are amnesiac of their grass roots. They impose policies from the top down without engaging the masses (a recipe for hegemonic dictatorship). They display the same impoverishing symptoms as the globalising, capitalist and techno-scientific environment (Du Toit 2009:16). Thus Du Toit concludes that poverty is closely linked to illiteracy, corruption, disease, crime, alcoholism, subservience, dependence, and lack of responsibility. Abuse of freedom and responsibility is not race specific but is part of the human condition.

\section{Black Theology and African Democracy}

It is a common observation that African democracy replicates Western style democracy, with the result that millions of black people are realising that African democracy is pervasively characterised by dictatorship, tyranny, corruption and poor service delivery which is also due to a lack of discipline and inefficiency (Mulemfo 2000:88). In Zimbabwe, for example, the policy of "one person one farm" is just a political ploy - covering up for the phenomenon of multi-farm owners implicating many senior government officials prior to the Government of National Unity (GNU). The pertinent question is, how African is African democracy? Is this not the lynchpin of where African democracy goes wrong? Clearly there is a need for putting "new wine into new wine skins" (Lk 5:36-38).

Democracy, understood as the rule of the people by the people, is guaranteed by the country's constitution. It affirms equal opportunities for all, and respect for human dignity, rights and freedom (The Constitution of the Republic of South Africa 1997, § 7-39). Democracy urges for participation of all people in the making and implementation of laws that govern them. In the new and post-colonial South Africa, Black Theology is challenged to 
engage in a creative discourse to discern the African contribution for authentic participatory democracy and to provide prophetic advocacy for the liberation of millions of black people suffering under tyrannical post-colonial African governments.

Facing the need to redefine black identity, Black Theologians have to grapple creatively with the Gospel and culture(s) to come up with a black contribution to a multicultural, interethnic and fast evolving techno-scientific environment. They have to probe the integrity of the so-called "African solutions to African problems" (e.g. Thabo Mbeki's political and economic initiatives of the African Renaissance and NEPAD) (Mulemfo 2000) to correct and expand the view. Critical issues revolve around credible land reform, indigenisation as regards blacks' access to the country's resources and contribution to national growth and development and political leadership. Black Theology needs to engage in a multi-sectorial dialogue with culture, politics, and the global free market economy.

Engaging in prophetic discourse, Black Theologians need to adopt what Albert Nolan called "conjunctural analysis". Van der Water (2001:39) explains that this is an analysis that goes beyond a social analysis of the general situation. It discerns the particular crisis in terms of the conjunction or meeting of opposing forces. There is a need for Black Theology to come up with a theology of the land and for interrogating new policies, for example South Africa's Black Economic Empowerment (BEE) (Peng 2008:29).

\section{Black Theology of Liberation and Dialogue with Culture}

According to Kobia (2004:47), inclusiveness and holistic participation are essential factors for the quality of prophetic witness. We have also seen that these are the most sought after factors for a prophetic dialogical Black Theology of liberation and for multicultural living. Black Theologians are challenged to review essential cultural elements to expand the vision and make a significant contribution to multicultural and interethnic life of post-apartheid and post-colonial Africa. This, according to Nyamiti (1973:29-30) is a process of rejection, correction, completion and refinement of essential cultural values in the light of Gospel values.

For Bantu people, the searchlights for blacks' contribution to multicultural living are on unpacking the ethic of ubuntu, (Shona: unhu), elaborated as cognates ergo sum, "I am related, therefore I am" (Pobee 1992:66). This orientation challenges Black Theologians to critically engage cultural values of communal personhood, ontology and epistemology in the quest for a black contribution to the macro-culture, that is to multicultural living influenced by globalisation and an increasingly developing techno-scientific world. Major themes are "communal solidarity" (Shona: umwe, "togetherness"), friendship (Shona: ushamwari) and "hospitality" (Chimhanda 2002:129-131). Clearly, these cultural elements are axiomatic for developing an African identity that is open to a historically changing situation and that welcome difference - the wealth it brings to multicultural living. These essential concepts can enter into creative dialogue with liberating biblical motifs of stewardship and a predilection for the anawim, provision for the "poor of Yahweh" identified as a trilogy of the "widow, stranger and orphan" (Ex 22:21-24; 23:9; Lev 19:33-34; Deut 27:19;24:17).

Stewardship is a biblical value. It has its foundation in the "integrity" or "goodness of creation" (Genesis 1). This captures issues of mutual interdependence of all creation, the impulse for responsible use of creation, and respect for human dignity, property and freedoms. The world and all creation are "God's household", the oikoumene (cf Ps 23). The nation's resources are part of the oikoumene and are to be made available to all. The New 
Testament gives the litmus test for good stewardship or governance as, that people "receive their portion of food at the proper time" (Lk 12:42-43) and to be found trustworthy as stewards of God's grace (1 Cor 4:1-2).

Black Theology interventions need to concentrate on education and empowerment for self-knowledge, self-affirmation and self-actualisation for responsible black participation in leadership, economic growth and multicultural living. Critical issues are the search for an inclusive and open identity that welcomes difference and responsible land reform and political leadership that enable economic and ecological sustainability. The latter aspect is captured in the concept of stewardship.

\section{Black Theology and the Agrarian Reform}

We have seen that the blueprint for a successful land reform is good stewardship. Land reform (acquisition, redistribution) is an issue that touches the raw nerve of post-apartheid black South and post-colonial Africa. For example Mofokeng, in "Land is our mother", names the "brutal dispossession" of blacks of their land and the consequent impoverishment of masses of black people in apartheid South Africa "a sin" (cf. De Gruchy 2005:232233). In these contexts, most people agree with the need for land reform to settle millions of blacks displaced and impoverished by previous aforementioned dominant systems. However, the majority of people (including blacks themselves) have misgivings with the method of land acquisition and resettlement in that the process is often accompanied with state sanctioned violence (looting, vandalising of agricultural equipment, corruption in managing agricultural inputs) and poor service delivery by the new farmers. A case in point is Robert Mugabe's fast truck land acquisition that has ruined commercial farming and consequently the Zimbabwe agrarian economy. Although South Africa is careful to avoid the mistake of Zimbabwe, poor service delivery applies equally to post-apartheid democratic South Africa's land reform policy.

In the search of a liberating land policy, Black Theologians need to unpack heavily loaded clichés like 'land to the people' and "reclaiming ancestral land". It can be asked whether descendants of colonial masters (who also have their forebears, umbilical cords and placentas buried in African soil) have no legitimate claim to the national cake. Giving black Africans the benefit of the doubt that the land belongs to them, how does one justify Africans' ownership claim for the improvements done to the land by the white people over a couple of decades? African and Black Theologians must look truth in the face of opposition and condemn such violence and reversed racism.

Another negative aspect of the violent acquisition of white commercial farms is that the new farmers have become a liability to the whole nation. In Zimbabwe, it is now a common feature to see good prime land that in colonial times was commercially highly productive, lying derelict. There has been unrestrained deforestation, destruction of agricultural mechanisation infrastructure with the result that Zimbabwe, that had been the breadbasket of the region, has now been reduced to dependence on food handouts from donor agencies. And, of course it is known that good nutrition makes for good health. In this vicious cycle of events (including drought), erratic land reforms of Zimbabwe are indirectly responsible for the cholera outbreak and the perishing of many people in 2008.

The concern for good stewardship for both land and people, should spur Black Theology on to advocate for education for responsible use of land and adopting an attitude of autonomy (self-affirmation, self-development) rather than depending on government handouts and capitalising on other people's achievements. Black theologians in South 
Africa can advocate for the government to acquire land for the masses of black people in a fair manner as undergirded in the "willing buyer, willing seller" and compensating farmers for land lost through the land restitution programme. But this also has its weaknesses in that the process is slow due to the large amounts of money required. Another positive avenue to explore is South Africa's "use it or lose it" (ZimOnline, 3 February 2010) policy that focuses on "support" for emerging black commercial farmers through skills training to promote good stewardship for the whole nation.

\section{Black Theology of South Africa in Dialogue with Post-colonial Africa}

In the context of apartheid, South Africa as the last colony to be liberated in black Africa, against the backdrop of black solidarity and inter-regional co-operation, Black Theologians of South Africa cannot ignore the plight of millions of Africans whose rights, dignity and freedom are violated and denigrated by tyrannical post-colonial African regimes. In the case of neighbouring Zimbabwe, the people are reduced to non-persons in that they are disenfranchised and held to ransom by a leader who holds on to power tenaciously, refusing to concede defeat after elections. Furthermore, there is no rule of law and this promotes decay of the country's moral fabric.

Indeed, in the period of dormancy, Black Theology has failed to speak about pressing situations in, for example, neighbouring Zimbabwe (except the faint voices from e.g. the Nobel Prize laureate, Archbishop Desmond Tutu). It has missed the kairos (opportunity and the responsibility that goes with it), that is, to show prophetic agency in the face of gross crime against humanity. Black Theology needed to engage in critical discourse with interregional interventions of SADC and AU - with the so-called "African solutions to African problems". In that stance they betrayed millions of suffering Zimbabweans in the conspiracy of silence.

Conspiracy of silence in the Zimbabwe conflict was clearly demonstrated in Mbeki's "silent diplomacy" policy. Inter-regional African interventions of the SADC and AU that brokered the transitional government of National Unity (GNU) power sharing government needed to be interrogated in the search of authentic liberation and reconciliation. But one can conclude that African political leaders of SADC and AU showed complicity in compromising an election result, and therefore, the will of the people concerning a change of political leadership. Christie (2010:7 citing Leo Tolstoy) throws insight into conspiracy of "power sharing" as follows:

This is the great meaning of power sharing: the long years of endless conspiracy by all those who should know better, who share their power to create a monster-defeated ... yet he is miraculously resurrected. All rapturously greet the man they cursed the day before and will case again a month later.

This gives food for thought for Black Theologians.

\section{Black Theology of Liberation in Dialogue with African Theology}

Tutu (in his article, Black Theology/African Theology - soul mates or antagonists? [1975]) points to the mutual relation of Black Theology and African Theology. In colonial and apartheid systems, there was a clear distinction between Black Theology and African Theology. The former concentrated on the liberation of blacks from racial oppression while the latter concentrated primarily on Christian evangelisation and inculturation. Even so, Black Theology and African theology shared a common history and concern against white supre- 
macy and its relation to the Gospel of Christ (Hopkins 1999:163-164). It appears that there is mutual influencing between liberation and inculturation in that the latter is liberating in advocating the good news that people feel at home in their own culture and church.

The post-colonial and apartheid times have introduced new perspectives or problems that need rethinking in the search for new solutions. From the above exposition, it appears that there is mutual influence between Black and African Theologies. For example, cultural values are explored in search for black identity and black contributions to multicultural and interethnic life. We can conclude that since theology is interdisciplinary, both Black Theology and African Theology have the liberty to use the resources at their disposal while maintaining their distinctive foundational focus or emphases.

\section{Black Theologians as Proactive Agents of History}

The phenomenon of transitional governments to democracy, for example, power-sharing governments prolific in Africa, shows that Africa is in crisis. A crisis situation is a kairos (Kairos Document of South Africa, 1985) as shown above. The challenge for Black Theologians is seize the opportunity and the responsibility that goes with it. This aspect highlights the need for attentiveness in mapping out the liberation process.

Liberation theology as critical discourse is informed by the past and the present and looks into the future. Engaging the memory of oppression and marginalisation in apartheid and colonial times and thereafter, through dysfunctional democracies in Africa, Black Theologians, as proactive agents of history, need to be on guard that mistakes of the past are not repeated today. Maimela (1989:iii) was prophetic in saying that in the new South Africa, Black theologians' challenge is to provide guidance "for both Black and white Christians" to work for justice for everyone so as to prevent rulers from becoming oppresssors themselves.

Black Theologians of South Africa as guardians and pace setters (proactive agents of change) for good governance, also have other lessons to learn from post-colonial Africa North of the Limpopo. For example, there are signs that South Africa is slowly moving into Zimbabwe style loyalty to one party that is linked to the liberation struggle - to state leadership supported by war veterans and youth militia (a move that is one of the root causes of the catastrophic decline of the country in the last 30 years of independence from colonial power).

\section{Conclusion}

The place for Black Theology of liberation as the theology of the signs of the times in postapartheid South Africa and post-colonial Africa has been affirmed. In relation to the historical development of liberation as a result of the human condition and the influence of globalisation and the techno-scientific environment, Black Theology has to grapple with new and complex issues that include redressing socio-economic and political imbalances and redefining new identities for multicultural, interethnic living. It cannot be overemphasised that because Black Theology has to engage in prophetic witness and advocacy in response to the salvific mission from God/Christ that is inclusive of all people, Black Theology is dialogical. In this context, it has to maintain a creative dialogue with African theology while maintaining its identity or emphasis. 


\section{BIBLIOGRAPHY}

Boesak, A 1976. Farewell to innocence. Johannesburg: Raven Press.

Du Toit, CW 2009. African challenges: unfolding identities. Pretoria: University of South Africa.

Chimhanda, FH 2002. An incarnational Christology set in the context of narratives of Shona women in present day Zimbabwe. (University of South Africa: Unpublished thesis).

Christie, R. 2010. "Power sharing and scarcity: determinative economic master narratives", in Power sharing and African democracy. Du Toit, C.W. (ed). Pretoria: University of South Africa.

Cone, JH 1975. God of the oppressed. New York, San Francisco: HaperSanFrancisco.

Rights. Missiology, Vol. XXVI, no. 1, pp.163-176.

Hopkins, DN 1990. Black Theology in the USA and South Africa: politics, culture and liberation. Maryknoll, New York: Orbis Books.

Hopkins, DN 1999. Black Theology of liberation. Maryknoll, New York: Orbis Books.

Human Rights Watch Organisation 2008. Neighbours in need: Zimbabweans seeking refuge in South Africa.

Kee, A 2005. "The criticism of Black Theology is transformed into criticism of politics' Karl Marx", in The quest for liberation and reconciliation: essays in honour of J. Roberts. pp.46-52. Roberts, JD \& Battle, M (eds.) Westminster: John Knox Press.

Kobia, S 2004. "The nation-state in Africa: violence and quests for life with dignity" in Church-state relations: a challenge for African Christianity. Mugambi, JNK \& Küschner-Pelkmann, F (eds.). Nairobi, Kenya: Acton Publishers.

Maimela, S \& Hopkins, D (eds.) 1989. We are one voice: Black Theology in the USA and South Africa. Cape Town, Johannesburg: Blackshaws.

Maimela, S 1989. Proclaim freedom to my people. Braamfontain: Skotaville Publishers.

Maluleke, TS July, 1997. “The 'smoke screens' called Black and African theologies - the challenge of African women theology”. Journal of Constructive Theology, 3.2, pp.39-61.

Mofokeng, TA "Land is our mother: a Black Theology of the land". De Gruchy JW \& De Gruchy S 2005. The Church Struggle in South Africa (cf. Guma, M \& Milton, L 1997. "The African Challenge to the Church in the $21^{\text {st }}$ century." Cape Town: Salty Print) Minneapolis: Fortress Press.

Mosala, IJ 1989. Biblical hermeneutics and Black Theology in South Africa. Grand Rapids, Michigan: WB Eerdmans.

Motlhabi, BM 1989. "Black Theology and Authority". Challenge of Black Theology in South Africa, p.121-170.

Mugambi, JNK 1999 "Religion in social transformation", in Democracy and reconciliation: a challenge for African Christianity. Magesa, L \& Nthamburi, Z (eds.). Nairobi: Acton Publishers.

Mugambi, JNK \& Küschner-Pelkmann, F (eds.) 2004. Church-state relations: a challenge for African Christianity. Nairobi, Kenya: Acton Publishers.

Mulemfo, MM 2000. Thabo Mbeki and the African Renaissance. Pretoria: Actua Press.

Nyamiti, C 1973. The scope of African Theology. Uganda, Kampala: Gaba Publications. 
Peng, MW 2008. Global business. Mason, USA: South-Western Congage Learning.

Pobee, JS 1992. Skenosis: Christian faith in an African context. Gweru, Zimbabwe: Mambo Press.

Roberts, JD 1987. Black Theology in dialogue. Westminster: John Knox Press.

Roberts, JD 1994. Liberation and reconciliation. Maryknoll, New York: Orbis Books.

Roberts, JD \& Battle, M 2005. The quest for liberation and reconciliation: essays in honour of J.Roberts. Westminster: John Knox Press.

Schreiter, RJ Jan 1992. "Reconciliation as a missionary task". Missiology: an international review, vol. XX, no. 1, pp. 3-10.

Sparks, A 2003. Beyond the miracle. Johannesburg \& Cape Town: Jonathan Ball.

The Constitution of the Republic of South Africa. http.//www.constitutionalcourt.org.za

South African Black theologian 1985. The Kairos Document: challenge to the Church a theological comment on the political crisis in South Africa. Wikipedia, the free encyclopaedia.

Tutu, DM 1975. "Black Theology, African Theology - soul mates or antagonists?" Journal of Religious Studies, 32.2:p.25-33.

Tutu, D 1999. No future without forgiveness. London-Sydney-Auckland-Johannesburg: Rider.

Van der Water, D 2001. "A legacy for contextual theology: prophetic theology and the challenge of the kairos" in Towards an agenda for contextual theology. McGlory, TS \& Kaufmann, LT (eds.). Pietermaritzburg: Cluster Publications.

ZimOnline. South Africa moves to ensue productivity on land, 3 March 2010. 